\title{
Początek działalności arcypasterskiej władyki Hilariona Ohijenki w roku 1940
}

Słowa kluczowe: Hilarion Ohijenko, Kościół prawosławny, Ukraińcy, Chełm, biskup. Keywords: Ilarion Ohiienko, the Orthodox Church, Ukrainians, Kholm, bishop.

The metropolitan Ilarion Ohiienko (1882-1972) was prominent Ukrainian Orthodox cleric, linguist, church historian, and cultural figure. In May 1937 the wife of Prof. Ivan Ohiienko died. And soon, in 1940, upon the recommendation of the Ukrainian Church Rada, the Council of the Orthodox Church in the Generalgouvernement, headed by metropolitan Dionisii Valedynskyi, elected Prof. I. Ohienko as Bishop of Kholm and Pidliashia. The Metropolitan of Warsaw Dionisii tonsured Ivan Ohiienko as a monk at St. Onuphrius monastery in Jableczna on October 9, 1940, giving him the name of Ilarion. The next day, Metropolitan Dionisii ordained him a deacon, and on October 11 his ordination as hieromonk took place, as well as his promotion to the rank of archimandrite. The episcopal nomination of archimandrite Ilarion took place in the Kholm Cathedral on October 19, 1940 and his episcopal ordination took place the next day, presided by Metropolitan Dionisii of Warsaw. Ohiienko began to Ukrainianize the Orthodoxy in the Kholm region, by introducing Ukrainian practices in the church rite and the use of Ukrainian in services and ordaining several Ukrainian priests. In August 1951 he was elected metropolitan of Winnipeg and head of the Ukrainian Orthodox Church of Canada.

Początek II wojny światowej otworzył nowy etap w życiu Iwana Ohijenki (1882-1972), mieszkającego wówczas w Warszawie. Pakt Ribbentrop-Mołotow doprowadził do podziałów Polskiego Autokefalicznego Kościoła Prawosławnego (PAKP). Diecezja warszawska weszła w skład Generalnego Gubernatorstwa, cztery inne - znalazły 
się w składzie ZSRR. Metropolita warszawski Dionizy Waledyński (1879-1960) został usunięty przez Niemców z funkcji zwierzchnika PAKP. Początkowo okupanci zamierzali podporządkować organizację prawosławną na podbitych terenach arcybiskupowi berlińskiemu i niemieckiemu Serafinowi Lade, który należał do Rosyjskiego Kościoła Prawosławnego za Granicą i był uważany w Berlinie za głównego eksperta w sprawach cerkiewnych. Pierwotnie Ukraińcy pokładali w nim pewne nadzieje, licząc na to, że władyka Serafin będzie sprzyjał ukraińskiemu odrodzeniu cerkiewnemu. Wkrótce okazało się, że nadzieje te były płonne. Jako wychowanek tradycji rosyjskiej hierarcha zaczął prowadzić politykę prorosyjską ${ }^{1}$.

Władze niemieckie oddały prawosławnym,,serce życia duchownego Ukraińców" - sobór Narodzenia Bogurodzicy w Chełmie, a także inne cerkwie, które wcześniej zostały im odebrane przez katolików. Iwan Ohijenko był wówczas przewodniczącym Ukraińskiej Rady Cerkiewnej (URC) w Warszawie, która opowiadała się za organizacją Ukraińskiej Autokefalicznej Cerkwi Prawosławnej i domagała się usunięcia arcybiskupa Serafina oraz powrotu na katedrę warszawską metropolity Dionizego. W czerwcu 1940 r. Iwan Ohijenko został wybrany na przewodniczącego rady cerkiewnej przy Centralnym Ukraińskim Komitecie Narodowym (CUKN) w Krakowie ${ }^{2}$. URC wspierała niemiecka administracja okupacyjna. W czerwcu $1940 \mathrm{r}$. cerkiewna rada w Chełmie z ks. Iwanem Lewczukiem na czele wybrała Iwana Ohijenka jako kandydata na stanowisko biskupa chełmskiego. Należy dodać, że jeszcze w 1932 r. zaproponowano Ohijenkę na biskupa łuckiego, lecz wtedy nie zgodził się on ze względu na żonę Dominikę, z którą nie chciał się rozstawać.

\footnotetext{
${ }^{1}$ А. Свитич, Православная Церковь в Польше и ее автокефалия, [w:] Православная Церковь на Украине и в Польше в ХХ столетии. 1917-1950 г2., Moskwa 1997, s. 258; A. Mironowicz, Kościół prawosławny na ziemiach polskich w XIX i XX wieku, Białystok 2005, s. 201.

${ }^{2}$ В. Кубійович, Украӥниі в Генеральній Губернії. 1939-1941. Історія Українського Центрального Комітету, Chicago 1975, s. 302-305, 308.
} 
Ale teraz, ze względu na to, że wśród duchowieństwa Generalnego Gubernatorstwa, oprócz archimandryty Palladiusza (Wydybidy), nie mamy odpowiednich kandydatów na stanowisko biskupów ukraińskich, a sprawa ukraińskiej cerkwi nabiera poważnego charakteru, ponieważ obywatele ukraińscy będa na to nalegać, on będzie musiat zgodzić się na to, żeby nadać Ukraińskiej Cerkwi Prawostawnej należny kierunek i odbudować ja nie tylko forma, ale i treścia ukraińska - przekazywał rozmowę z I. Ohijenką Atanazy Nesterenko³. Zaraz po śmierci żony Dominiki (19 maja 1937 r.), Iwan Ohijenko po pewnych rozważaniach zgodził się na propozycję rady cerkiewnej i został kandydatem na biskupa. Wyraził również zgodę, by stanąć na czele największej w Generalnym Gubernatorstwie chełmsko-podlaskiej eparchii prawosławnej (95\% jej prawosławnych mieszkańców stanowili Ukraińcy).

Przewodniczący CUKN W. Kubijowycz wspominał, że znalezienie odpowiedniego kandydata na biskupa nie było łatwe. Pisał on m.in.: Z różnych stron wskazywano na prof. Ohijenko jako na kandydata na biskupa chetmskiego, gdyż, chociaż nie byt on mnichem, stale zajmowat sie problemami Cerkwi, byt osoba znana i swoja postawa gwarantowat, że jako wtadyka prawostawny zawsze będzie trzymać linię ukraińska ${ }^{4}$.

Latem 1940 r. urząd generalnego gubernatora Hansa Franka rozpatrywał możliwość wyświęcenia biskupów ukraińskich za pomocą archijereji jurysdykcji Patriarchatu Konstantynopolitańskiego Sawwatija Wrabca ${ }^{5}$ Sergiusza Korolowa. Jednak taki scenariusz wyglądał zbyt nieprawdopodobnie, dlatego wkrótce z niego zrezygnowano ${ }^{6}$.

\footnotetext{
${ }^{3}$ А. Нестеренко, Величне свято, „Слово Істини” 1950, nr 1-2, s. 19.

${ }^{4}$ В. Кубійович, Українці..., ор. cit., s. 308.

${ }^{5}$ O nim dokładniej zob.: P. Marek, V. Bureha, J. Danilec, Arcibiskup Sawatij (1880 1959): Nástin života a díla zakladatelské postavy pravoslavné církve v Československé republice, Olomouc 2009, s. 250.

${ }^{6}$ М. Шкаровский, Крест и свастика: Наџистская Германия и Православная Церковь, Moskwa 2007, s. 109.
} 
Po negocjacjach I. Ohijenki z metropolitą Dionizym w Otwocku w lipcu 1940 r. ten ostatni zgodził się razem z biskupem lubelskim Tymoteuszem Szretterem, by udzielić święceń kapłańskich Ohijence. Tymczasem wspomniany wcześniej biskup Tymoteusz został przez Niemców odsunięty od spraw zarządzania życiem cerkiewnym ze względu na swoje poglądy polonofilskie. Hierarcha przebywał w klasztorze św. Onufrego w Jabłecznej. Ważne było, aby Waledyński na pewien czas formalnie stanął na czele Kościoła. Po wyświęceniu trzech biskupów na katedry w Warszawie, Chełmie i Krakowie I. Ohijenko wystąpił z propozycją powołania soboru hierarchów w celu wybrania nowego metropolity, licząc na to, że stanowisko to obejmie on sam i w ten sposób zostanie zwierzchnikiem Cerkwi. Kierownik działu do spraw cerkiewnych rządu generalnego gubernatora Hans Adolf Wilden zgadzał się z tą propozycją, ale uważał, że władyka Dionizy może ponownie zarządzać Cerkwią tylko przez okres trzech miesięcy ${ }^{7}$.

Za sprawą aktywnej działalności byłego biskupa grodzieńskiego Sawy Sowietowa w Stambule, ekumeniczny patriarcha Beniamin Psomas został poinformowany o sytuacji cerkiewnej na terenie okupowanej Polski. W związku z czym 9 lipca 1940 r. zwołano Synod, na którym uznano metropolitę Dionizego za zwierzchnika Cerkwi Prawosławnej w Generalnym Gubernatorstwie. Ta decyzja sprawiła, że rząd H. Franka poparł Waledyńskiego a nie Ohijenkę na stanowisko zwierzchnika Cerkwi Prawosławnej ${ }^{8}$.

Niemcy proponowali arcybiskupowi Sierafinowi, by ten wziął udział w wyświęceniach biskupów ukraińskich, lecz on zrezygnował ze względu na fakt, że Rosyjska Cerkiew Prawosławna za Granicą nie uznawała autokefalii polskiej.

We wrześniu 1940 r. profesor I. Ohijenko przybył z Warszawy do Chełma, by bliżej zapoznać się z prawosławnymi mieszkańcami

\footnotetext{
${ }^{7}$ Ibidem, s. 110.

${ }^{8}$ Ibidem, s. 112.
} 
Chełmszczyzny. Uczony wygłosił szereg wykładów na temat historii Cerkwi. Przed Soborem Biskupów Cerkwi Prawosławnej w Generalnym Gubernatorstwie I. Ohijenko zabiegał o następujące kroki: 1) prosił o nie czynienie oporu w odrodzeniu tradycji starej Cerkwi ukraińskiej na Chełmszczyźnie, gdyż w 99\% diecezja chełmsko-podlaska składała się z Ukraińców; 2) miało nastąpić wyświęcenie jeszcze jednego biskupa Ukraińca, aby na soborze biskupów interesy ukraińskie wiernych były należycie reprezentowane; 3) należało sprowadzić z Warszawy do Chełma drukarnię i bibliotekę. Te postulaty poparł metropolita Dionizy, po czym zaczęto przygotowywania do chirotonii Ohijenki na biskupa 9 .

23 września 1940 r. na Wawelu w Krakowie generał gubernator Hans Frank, w obecności Iwana Ohijenki, ks. Mikołaja Malużyńskiego i przedstawicieli CUKN z Włodzimierzem Kubijowyczem na czele, przyjął władykę Dionizego. Ogłoszono wznowienie władzy kanonicznej metropolity Dionizego w Generalnym Gubernatorstwie, a ten zapewnił o swojej lojalności wobec władz niemieckich i obiecał wyświęcić Ohijenkę ${ }^{10}$.

30 września 1940 r. Sobór Biskupów Cerkwi Prawosławnej w Generalnym Gubernatorstwie przy udziale metropolity Dionizego i biskupa Tymoteusza przyjął uchwałę o podziale Metropolii Warszawskiej na trzy eparchie: warszawsko-radomską, chełmsko-podlaską i krakowsko-łemkowską. Eparchia chełmsko-podlaska, ze względu na swoje cerkiewno-historyczne znaczenie, była podniesiona do stopnia arcybiskupstwa, a jej eparchialny archijerej otrzymał tytuł arcybiskupa chełmsko-podlaskiego. W uchwale Soboru czytamy m.in.: W związku z utworzeniem dwóch nowych eparchii, których mieszkańcy to wyłacznie ludność ukraińska, na stanowisko arcybi-

${ }^{9}$ М. Тимошик, ,„лишусь навіки з чужиною...”. Митрополит Іларіон (Іван Огієнко) і украӥнське відродження, Winnipeg-Kijów 2000, s. 103.

${ }^{10}$ I. Власовський, Нарис історії Украӥнської Православної Церкви, Kijów 1998, t. 4: (ХХ ст.), сz. 2, s. 183; „Краківські вісті” 1940, nr 96, s. 1-2; „Церковні відомості" 1943, nr 1, s. 4-5. 
skupa chetmsko-podlaskiego obieramy profesora Studium Teologii Prawosławnej [dawnego] Uniwersytetu Warszawskiego dr Iwana Ohijenke, znanego naukowca, działacza cerkiewnego i kulturalnego dla dobra narodu ukraińskiego ${ }^{11}$.

6 października 1940 r. I. Ohijenko napisał słowo pożegnalne, adresowane do osób, które znały go jako naukowca, profesora, ministra, i z którymi dzielił on skomplikowane życie politycznego emigranta: Wybaczcie mi wszystko! Odchodzac od życia świeckiego i zostajac mnichem, zwracam się do wszystkich z goraca prośba o wybaczenie mi wszystkich moich grzechów, które popetniłem słowem, myśla lub uczynkiem. Wkrótce przestanę być Iwanem Ohijenko, a stanę się pokornym, nabożnym mnichem modlacym się o lepszy los narodu ukraińskiego. Dlatego po raz drugi i trzeci czule proszę, by wybaczyć mi wszystko, czym kiedykolwiek przed kimś zawinitem ${ }^{12}$.

9 października 1940 r. w monasterze św. Onufrego w Jabłecznej metropolita Dionizy dokonał postrzyżyn mniszych I. Ohijenki, który przyjął imię Hilarion (ku czci Hilariona Pieczerskiego - pierwszego Rusina - metropolity kijowskiego). Następnego dnia odbyła się jego chirotonia na diakona, a 11 października - na hieromnicha. Po liturgii tego dnia w specjalny sposób ks. Hilarion został archimandrytą. Przebywając w klasztorze, odprawiał codzienne nabożeństwa.

Ciekawe wspomnienia o spotkaniu w Chełmie z Hilarionem Ohijenką zostawiła studentka chełmskiego gimnazjum Katarzyna Wasyliw-Sydorenko: Miasto Chetm ożyło, zabłyszczały flagi ukraińskie. Do Chetma przybyto prawie całe duchowieństwo chetmsko-podlaskie, delegacje różnych instytucji ukraińskich $i$ wierni. Spotkanie archimandryty Hilariona odbyło się 18 października i trwało blisko 17 godzin. Uczniowie gimnazjum dwoma szeregami obstawili droge, zaczynajac od schodów na Świętą Górę Danyłowa, aż do drzwi głównych soboru. Z mojego miejsca zobaczyłam, jak zblizała się procesja kleru na czele

${ }^{11}$ „Церковні відомості” 1943, nr 1, s. 5.

${ }^{12}$ М. Тимошик, ,Лишусь навіки з чужсиною..., op. cit., s. 104. 
z ks. I. Łewczukiem. Szli diakoni, chór i wierni. Wszyscy zatrzymali sięniedaleko schodów, po których w czarnej szacie i kłobuku schodzit archimandryta Hilarion. Rozlegty się dzwony i śpiew, posypaty się kwiaty. Wygłoszono powitanie po czym archimandryta wraz z klerem udat się do katedry ${ }^{13}$.

Uroczystości z okazji przystąpienia ks. Hilariona do pełnienia obowiązków ordynariusza prawosławnej eparchii chełmsko-podlaskiej odbyły się 19 października 1940 r. Wtedy to Ohijenko wygłosił przemówienie na temat: Trudne zadania ukraińskiego archijereja. Po raz pierwszy nowy biskup przedstawił w nim swoją życiową maksymę „służyć narodowi - znaczy służyć Panu Bogu”, którą kierował się w ciągu całej swojej posługi arcypasterskiej: Historia naszej Cerkwi pokazuje jak Naród Ukraiński zawsze bardzo mocno był związany ze swoja Cerkwia i kiedy była ona ludowa i narodowa [...] A lubićznaczy stużý, a stużyć Panu Bogu - znaczy stużyć Jego Narodowi. Odrodzona Cerkiew odrodzi i nasz Naród. Niech wszyscy dobrze pamiętaja, że kultura ukraińska była stworzona przez Cerkiew Ukraińska [...] U kogo mocna Cerkiew, u tego mocny Naród! ${ }^{14}$.

Następnego dnia w soborze Narodzenia Bogurodzicy na Świętej Górze Danyłowej w Chełmie Hilarion przyjął święcenia biskupie. Chirotonii dokonało trzech hierarchów prawosławnych: metropolita warszawski Dionizy, arcybiskup praski Sawwatij i biskup lubelski Tymoteusz. Podczas wielkiego ingresu metropolita Dionizy podniósł Hilariona do godności arcybiskupa chełmskiego i podlaskiego. Świadek tamtych wydarzeń inżynier A. Nesterenko w następujący sposób wspominał o uroczystościach trwających w Chełmie przez kilka dni: Cała Święta Góra Danyłowa była posprzątana i udekorowana zółto-błękitnymi flagami ukraińskimi i setkami lamp elektrycznych. Wieczorem $i$ w nocy te lampy jasno oświecaty cała Święta Górę Da-

${ }^{13}$ К. Василів-Сидоренко, Молитва над останками Князя Данила, http://nadbuhom.pl/art_1492.html, [dostęp: 06.11.2016].

${ }^{14}$ Митр. Іларіон, Мої проповіді, Winnipeg 1973, s. 29-30. 
nytowa i podczas dni uroczystych. A poza tym, na górze w różnych miejscach byty rozstawione głośniki, radio i Mszę Święta było stychać na zewnatrz ${ }^{15}$.

Warto zaznaczyć, że przyjazd arcybiskupa Sawwatija zorganizowało Ministerstwo Spraw Zagranicznych Niemiec. Przedstawiciele tego resortu uważali, że ponieważ władyka Sawwatij należy do jurysdykcji patriarchy ekumenicznego, to jego udział w chirotonii będzie oznaczał uznanie jej przez Konstantynopol ${ }^{16}$. Hierarcha przywiózł ze sobą życzenia dla nowego biskupa od diaspory ukraińskiej w Czechach. Z kolei w dniu swojej chirotonii arcybiskup Hilarion wygłosił krótki apel Do prawosławnych Ukraińców w Pradze, w którym nawoływał ich do zjednoczenia się wokół swojej Cerkwi i tworzenia za jej pomoca swoich wartości duchownych ${ }^{17}$.

21 października 1940 r. Sobór Biskupów Cerkwi Prawosławnej w Generalnym Gubernatorstwie udzielił władyce Hilarionowi błogosławieństwa na kierowanie eparchią. Wyznaczono go na zastępcę metropolity Dionizego oraz upoważniono do otworzenia Chełmsko-Podlaskiego Konsystorza Cerkiewnego ${ }^{18}$. Następnie Ohijenko udał się do klasztoru św. Onufrego w Jabłecznej i wrócił do Chełma 2 listopada.

Na zlecenie H. Franka, 29 października 1940 r. w Krakowie państwowy sekretarz, dr Biler, przyjął arcybiskupa Hilariona i wręczył mu dekret upoważniający do zarządzania eparchią, a także prezent od generalnego gubernatora - kosztowną panagię ${ }^{19}$.

\footnotetext{
${ }^{15}$ А. Нестеренко, Митрополит Іларіон: Служитель Богові і народові, Winnipeg 1958, s. 56.

${ }^{16}$ М. Шкаровский, Крест и свастика..., ор. cit., s. 118.

${ }_{17}$ В.В. Бурега, Церковная жизнь украинской эмигращии в Чехии в 1920-1930е г2., [w:] ХІХ Ежегодная богословская конференция Православного СвятоТихоновского гуманитарного университета. Материаль, Moskwa 2009, t. 1, s. 299.

${ }^{18}$ Archiwum Warszawskiej Metropolii Prawosławnej, sygn. 1029-RII-6D (Prawosławna Cerkiew w Generał-Gubernatorstwie).

19 „Церковні відомості” 1943, nr 1, s. 8.
} 
3 listopada 1940 r. odbyła się uroczysta intronizacja na katedrę w Chełmie. Władyka Hilarion wspominał: Dla mnie biskupstwo nie byto kariera, a tylko świadoma krwawa Golgota ${ }^{20}$. W eparchii chełmsko-podlaskiej hierarcha rozpoczął szeroką działalność na rzecz ukrainizacji. Pod jego wodzą duchowieństwo rozwinęło intensywną działalność oświatową i kulturalno-wychowawczą wśród wiernych. Dużo uwagi poświęcano organizacji wydawnictwa, zbiorom i uporządkowywaniu biblioteki eparchialnej, tłumaczeniu modlitewników na język ukraiński. Aktywnie prowadzono działalność patriotyczną wśród młodzieży, organizowano obchodzenie ważnych wydarzeń i świąt narodowych ${ }^{21}$. Metropolita Hilarion włożył wiele wysiłku w przygotowania duchowieństwa, otwierając seminarium w Chełmie, którego program edukacyjny zbliżony był do programu akademii duchownej ${ }^{22}$. Działalność arcypasterska Hilariona w okresie chełmskim wymaga głębszej analizy, którą jednak utrudnia fakt, że archiwum diecezjalne zostało utracone.

Podsumowując, należy podkreślić, że chirotonia ideologa prawosławia ukraińskiego na katedrę chełmską była znaczącym osiągnięciem ukraińskiego ruchu narodowo-cerkiewnego i doprowadziła do wielkich zmian wewnętrznych Cerkwi Prawosławnej w Generalnym Gubernatorstwie. Chirotonia władyki Hilariona opierała się na kanonicznych liniach cerkwi moskiewskiej, warszawskiej i konstantynopolitańskiej. Pokornemu modlacemu się o lepszy los narodu ukraińskiego, jak zaczął podpisywać swoje listy hierarcha, dane było

\footnotetext{
${ }^{20}$ Іларіон. На Голготі. Украӥнська Православна Церква на Холмщзині під німияями: Спогади. 1939-1945, „Віра й Культура” 1966, nr 5 (149), s. 20.

${ }^{21}$ О.С. Лисенко, В. А. Гриневич, Роль етнічного чинника в міжконфесійних стосунках в Західній Украӥні напередодні німецьько-радянської війни, [w:] Украӥна і Росія в історичній ретроспективі, Kijów 2004, t. 2: Радянський проект для України, s. 176.

22 Листи від громадських діячів, представників української науки, культури $i$ церкви до Івана Огієнка (митрополита Іларіона), Kijów 2011, s. 36.
} 
odegrać nieprzeciętną rolę w życiu cerkiewnym Ukrainy w latach II wojny światowej i na emigracji.

\section{Bibliografia:}

1. Archiwum Warszawskiej Metropolii Prawosławnej, sygn. 1029-RII-6D (Prawosławna Cerkiew w General-Gubernatorstwie).

2. Marek P., Bureha V., Danilec J., Arcibiskup Sawatij (1880-1959): Nástin života a dila zakladatelské postavy pravoslavné cirkve v Československé republice, Olomouc 2009.

3. Mironowicz A., Kościót prawosławny na ziemiach polskich w XIXi XX wieku, Białystok 2005.

4. Бурега В. В., Церковная жизнь украинской эмиграчии в Чехии в 19201930-егг., [w:] ХІХ Ежегодная богословская конференция Православного Свято-Тихоновского гуманитарного университета. Материалы, Moskwa 2009, t. 1.

5. Василів-Сидоренко К., Молитва над останками Князя Данила, http:// nadbuhom.pl/art_1492.html [dostęp: 06.11.2016].

6. Власовський I., Нарис історї Украӥнської Православної Церкви, Kijów 1998, t. 4: (ХХ ст.), сz. 2.

7. Іларіон. На Голготі. Украйнська Православна Церква на Холмщині під німиями: Спогади. 1939-1945, „Віра й Культура” 1966, nr 5 (149), s. $18-24$.

8. Кубійович В., Украӥниі в Генеральній Губернії. 1939-1941. Історія Українського Центрального Комітету, Chicago 1975.

9. Листи від громадських діячів, представників украӥнської науки, культури і церкви до Івана Огієнка (митрополита Іларіона), Kijów 2011.

10. Митр. Іларіон, Мої проповідi, Winnipeg 1973.

11. Нестеренко А., Величне свято, „Слово Істини” 1950, nr 1-2, s. 15-28.

12. Нестеренко А., Митрополит Іларіон: Служитель Богові і народові, Winnipeg 1958.

13. О. С. Лисенко, В. А. Гриневич, Роль етнічного чинника в міжконфесійних стосунках в Західній Украӥні напередодні німецько-радянської війни, [w:] Україна і Росія в історичній ретроспективі, Kijów 2004, t. 2: Радянський проект для України. 
14. Свитич А., Православная Церковь в Польше и ее автокефалия, [w:] Православная Церковь на Украине и в Польше в ХХ столетии. 1917-1950 г2., Moskwa 1997.

15. Тимошик М., ,„Лишусь навіки з чужиною...”. Митрополит Іларіон (Іван Огієнко) і украӥнське відродження, Winnipeg-Kijów 2000.

16. Шкаровский М., Крест и свастика: Нацистская Германия и Православная Церковь, Moskwa 2007. 